УДК 378.147-057.36

DOI:

Юрій Бойчук, доктор педагогічних наук, професор, член-кореспондент НАПН Украӥни, ректор Харківського національного педагогічного університету імені Г.С. Сковороди

Юрій Таймасов, кандидат педагогічних наук, старший викладач-методист навчального пункту аварійно-рятувального загону спеціально призначення

Головного управління ДСНС Украӥни у Харківській області

Олена Зуб, кандидат сільськогосподарських наук, дочент, дочент кафедри фундаментальних дисииплін Національної академії Національної гвардії України

Артем Турчинов, кандидат педагогічних наук, доиент, заступник начальника кафедри фізичної підготовки та спорту Національної академії Національної гвардії України

\title{
МЕТОДИКИ ОЦНКИ КРИТЕРЇ̈В СФОРМОВАНОСТІ СТРУКТУРНИХ КОМПОНЕНТІВ ГОТОВНОСТІ МАЙБУТНІХ ФАХІВЦІВ СЛУЖБИ ЦИВІЛЬНОГО ЗАХИСТУ ДО САМОЗБЕРЕЖЕННЯ У ПРОФЕСІЙНІЙ ДІЯЛЬНОСТІ
}

У статті описано методики оцінки критеріїв сформованості структурних компонентів готовності майбутніх фахівців служби цивільного захисту до самозбереження у професійній діяльності. Описано розроблену комп'ютерну програму,що дає змогу здійснювати оцінку рівнів сформованості готовності майбутніх фахівців служби ичивільного захисту до самозбереження у професійній діяльності та сприяє включенню інформаційно-комунікаційних технологій в освітній процес профільного навчального закладу ДСНС Украӥни.

Наведено показники мотиваційного критерію, який включає позитивний характер мотивації курсанта до професійного навчання, щзо дасть змогу йому здійснювати самозбереження у подальшій професійній діяльності.

Ключові слова: методика; критерї̈; оцінка; структурні компоненти; служба цчивільного захисту; самозбереження.

Лim. 10.

Yuriy Boychuk, Doctor of Sciences (Pedagogy), Professor, Corresponding Member of the Ukraine National Academy of Pedagogical Sciences, Rector of

Kharkiv Hryhoriy Skovoroda National Pedagogical University Yuriy Taymasov, Ph.D. (Pedagogy), Senior Lecturer-Methodist of the Special Rescue Detachment Training Unit of the Main Directorate of the State Emergency Service of Ukraine in Kharkiv Region

Olena Zub, Ph.D. (Agriculture), Associate Professor of the Fundamental Disciplines Department of the National Academy of the National Guard of Ukraine Artem Turchynov, Ph.D. (Pedagogy), Associate Professor, Deputy Head of the Physical Training and Sports Department of the National Academy of the National Guard of Ukraine

\section{EVALUATION METHODS OF FORMATION STRUCTURAL COMPONENTS' CRITERIA OF FUTURE CIVIL PROTECTION SERVICE SPECIALISTS' READINESS FOR SELF-PRESERVATION}

The article describes the evaluation methods of the formation structural components criteria of the future civil defense service specialists' readiness for self-preservation in professional activities. It is described the developed computer program, which allows to evaluate the readiness levels of future the civil defense service specialists for self-preservation in professional activities and promotes the inclusion of information and communication technologies in the educational process in National university of civil defence of Ukraine. It is given the indicators of the motivational criterion, which includes the positive nature of the cadet's motivation for professional training, which will allow him to carry out self-preservation in further professional activity. It is emphasized that to assess the level of motivation of cadets to vocational training, we propose to use the modified method "Study of motivation of vocational training of cadets", proposed by V. Katashev. It is proposed to use the questionnaire to determine the level of formation of the motivational component of the readiness of the future specialist of the civil defense service for self-preservation in professional activities. The method "Study of motivation of professional training of cadets", created by the foreign scientist $V$. Katashev, which allows to find out the level of professional motivation of the cadet and if necessary to make changes in the initial educational process aimed at development of his professional self- 


\section{МЕТОДИКИ ОЦІНКИ КРИТЕРЇ̈ СФОРМОВАНОСТІ СТРУКТУРНИХКОМПОНЕНТІВ ГОТОВНОСТІ МАЙБУТНІХ ФАХІВЦІВ СЛУЖБИ ЦИВІЛЬНОГО ЗАХИСТУ ДОСАМОЗБЕРЕЖЕННЯ У ПРОФЕСІЙНІЙ ДІЯЛЬНОСТІ}

consciousness is described. The completeness and thoroughness of mastering the professionally oriented knowledge required by the cadet for self-preservation in further professional activity is an indicator of the cognitive criterion: To find out, it is proposed to use self-preservation test tasks, which the cadets had to answer, determining, in their opinion, the correct answer, and get the appropriate number of points for the correct answers. The formation of the cadet's design-constructive, executive and analytical-reflexive skills and abilities to implement self-preservation in professional activities is an indicator of the operational-activity criterion. It is emphasized that in order to establish this criterion it is proposed to develop a diagnostic card to assess the levels of formation of design and construction, performance and analytical-reflective skills and abilities of the cadet to implement self-preservation in professional activities. Completeness of the cadet's social creativity, his ability to self-education and self-development for the effective implementation of self-preservation in professional activities is an indicator of the reflexive-analytical criterion. Also described is a test to determine the level of social creativity of the individual. It is emphasized that for the future specialist of the civil protection service it is important to be able to quickly search for and effectively apply non-standard, original creative solutions to professional situations in self-preservation in professional activities. It is substantiated that the basis for the purposeful development of this ability is a set of properties that make up the creative and communicative potentials of the individual.

Keywords: methodology; criteria; assessment; structural components; civil defense service; self-preservation.

A наліз наукових джерел. На думку вітчизняних науковців (В. Бикова, М. Варій, Н. Вовчаста, О. Свсюков, М. Козяр, М. Коваль, В. Козлачков, П. Образцов, О. Островерх, О. Тимченко, Б. Шуневич) рівень готовності до самозбереження фахівців служби цивільного захисту у професійній діяльності можливо визначити завдяки методиці оцінки критеріїв сформованості структурних компонентів.

Постановка завдання. Описати методики оцінки критеріїв сформованості структурних компонентів готовності майбутніх фахівців служби цивільного захисту до самозбереження у професійній діяльності.

Виклад основного матеріалу. Методики оцінки критеріїв сформованості структурних компонентів застосовувались для вивчення динаміки розвитку як кожного окремого елемента готовності майбутнього фахівця служби цивільного захисту до самозбереження у професійній діяльності, так і сформованості готовності майбутнього фахівця служби цивільного захисту до самозбереження у професійній діяльності в цілому [1]:

- модифікована методика “Дослідження мотивації професійного навчання курсантів" В. Каташева (для встановлення рівня сформованості готовності за мотиваційним критерієм);

- тестові завдання з цивільного захисту (для 3'ясування рівня сформованості готовності за когнітивним критерієм);

- діагностична картка для оцінки рівня сформованості операційно-діяльнісного компонента готовності майбутнього фахівця служби цивільного захисту до самозбереження у професійній діяльності (для оцінки рівня сформованості готовності за операційнодіяльнісним критерієм);

- тест для визначення соціальної креативності особистості (для встановлення рівня сформованості готовності за рефлексивноаналітичним критерієм);

- тест для з'ясування здатності до самоосвіти та саморозвитку особистості (для визначення рівня сформованості готовності за рефлексивноаналітичним критерієм).

Для моніторингу рівнів сформованості готовності майбутніх фахівців служби цивільного захисту до самозбереження у професійній діяльності створено комп'ютерну програму "БКСЛ: Педагогічна діагностика готовності майбутніх фахівців служби цивільного захисту до самозбереження у професійній діяльності”.

Для роботи 3 програмно-тестувальним комплексом потрібне: а) технічне забезпечення: комп'ютер 3 процесором не менше Р700; відеоадаптер обсягом від 32 Мб; підключення до мережі Internet; б) програмне забезпечення: операційна систему, будь-який браузер [2].

Програма призначена для тестування груп курсантів до 140 осіб. Для роботи 3 програмою відкривається будь-який браузер (рекомендований Mozilla Firefox). Програма включає декілька блоків опитування.

До початку тестування вводиться прізвище та ім'я курсанта, взвод, обирається тип групи, тип тестування та натискається кнопка “почати тестування”. Після цього в наступному вікні можна обрати тест для проходження [3]

Наступним етапом $є$ проходженння тесту. Відповідаючи на питання, курсант натискає кнопки відповідей, тобто здійснює перехід до наступного питання.

Для полегшення навігації та з'ясування поточного стану користувача, в програмі постійно $€$ панель навігації та панель службового стану.

Після проходження тесту і отримання результату курсант має можливість вибрати 3 навігаційної панелі наступний тест та пройти його, або закінчити роботу з програмою, натиснувши 


\section{МЕТОДИКИ ОЦНКИ КРИТЕРЇ̈ СФОРМОВАНОСТІ СТРУКТУРНИХ КОМПОНЕНТІВ ГОТОВНОСТІ МАЙБУТНІХ ФАХІВЦІВ СЛУЖБИ ЦИВІЛЬНОГО ЗАХИСТУ ДОСАМОЗБЕРЕЖЕННЯ У ПРОФЕСІЙНІЙ ДІЯЛЬНОСТІ}

кнопку “Вихід”. У такому разі при повторній реєстрації цього самого курсанта він зможе пройти інші тести, окрім вже пройдених [4].

Викладач має змогу побачити списки курсантів (якщо він зареєстрований в адмінпанелі), які пройшли тест, їх результати, змінити або додати тест, а також експортувати дані в MS Excel для подальшої обробки результатів тестування.

Також викладач зі своєї панелі може виправити дані курсанта, переглянути створені тести або створити новий. У програмі реалізований контроль за помилками при внесенні даних.

Розроблена комп'ютерна програма дає змогу оцінити рівні сформованості готовності майбутніх фахівців служби цивільного захисту до самозбереження у професійній діяльності та сприяє включенню інформаційно-комунікаційних технологій в освітній процес профільного навчального закладу ДСНС України [5].

Мотивачійний критерій сформованості готовності майбутніх фахівиів служби цивільного захисту до самозбереження у професійній діяльності. Показником мотиваційного критерію $€$ позитивний характер мотивації курсанта до професійного навчання, що дасть йому змогу здійснювати самозбереження у подальшій професійній діяльність [6].

Для оцінки рівня мотивації курсанта до професійного навчання використано модифіковану методику “Дослідження мотивації професійного навчання курсантів”, запропоновану В. Каташевим. Вона дає змогу з'ясувати рівень професійної мотивації курсанта і при потребі внести зміни в освітній процес, спрямовані на розвиток його професійної самосвідомості. Професійна самосвідомість робить мотиви навчання стійкими, сприяє розвитку у курсанта уміння ставити цілі та досягати їх. А мотиви, як відомо, $\epsilon$ причиною інтересу до навчання як основи майбутньої професійної діяльності. Можна наголошувати, що активним у професійному навчанні буде той курсант, який розуміє необхідність у знаннях, потрібних йому для майбутньої професійної діяльності пов'язаної з ліквідацією надзвичайних ситуацій різних характерів [7].

Позаяк мотивація особистості включає емоційну та вольову сфери, то запропонований комплекс із 33 запитань містив частину запитань (18) на визначення рівня свідомого ставлення до проблем навчання і частину запитань (15) на виявлення емоційного сприйняття різних видів діяльності у ситуаціях, що постійно змінюються.

Івесь комплекс запитань був розділений на три сукупності, кожна 3 яких визначає ставлення курсантів до різних видів навчальної діяльності. Сукупність питань 1 включає твердження 1, 4, 7, 10, 13, 16, 19, 22, 25, 28, 31 і відображає індиферентне ставлення курсантів до навчання. У кращому випадку вони проявляють пізнавальну активність на рівні попередження претензій зі сторони викладачів або батьків. Сукупність питань 2 склали твердження 2, 5, 8, 11, 14, 17, 20, 23, 26, 29, 32; сукупність питань 3 - 3, 6, 9, 12, $15,18,21,24,27,30,33$. Друга і третя сукупності питань щодо мотивації навчання доводять соціальну стійкість курсантів, їх професійну цілеспрямованість, прагнення здобути додаткові професійні знання [8].

Відповіді на всі запитання курсанти оцінювали балами від 1 до 5 за такою шкалою: 1 бал впевнено “ні"; 2 бали - більше “ні”, ніж “так”; 3 бали - не впевнений, не знаю; 4 бали - більше “так”, ніж “ні”; 5 балів - впевнено “так”. Кожна із сукупностей питань могла набрати від 11 до 55 балів.

Високий рівень сформованості мотивації майбутнього фахівця служби цивільного захисту до професійного навчання відображає сума балів від 41 до 55; середній рівень - 26-40 балів, низький рівень - 11-25 балів.

В інструкції до методики “Дослідження мотивації професійного навчання курсантів" говориться, що процес професійної підготовки курсантів має підкріплюватися інтенсивною навколопрофесійною діяльністю на всіх етапах навчання. Курсантам із низьким рівнем сформованості мотивації до професійного навчання у профільних навчальних закладах ДСНС України необхідно приділяти посилену увагу з метою створення умов для підвищення їх мотивації.

Когнітивний критерій сформованості готовності майбутніх фахівияів служби ичивільного захисту до самозбереження у професійній діяльності. Показником когнітивного критерію $є$ повнота і грунтовність оволодіння професійно спрямованими знаннями, потрібними курсанту для здійснення самозбереження у подальшій професійній діяльності.

Для його з'ясування застосовувалися тестові завдання із самозбереження, на які мали відповісти курсанти, визначивши, на їхню думку, правильну відповідь, та отримати за це відповіднукількість балів.

Високий рівень опанування майбутніми фахівцями служби цивільного захисту професійно спрямованими знаннями визначається наявністю 33-48 балів, середній рівень - 21-32 балів, низький рівень - 1-20 балів [9]. 


\section{МЕТОДИКИ ОЦІНКИ КРИТЕРЇВ СФОРМОВАНОСТІ СТРУКТУРНИХ КОМПОНЕНТІВ ГОТОВНОСТІ МАЙБУТНІХ ФАХІВЦІВ СЛУЖБИ ЦИВІЛЬНОГО ЗАХИСТУ ДОСАМОЗБЕРЕЖЕННЯ У ПРОФЕСІЙНІЙ ДІЯЛЬНОСТІ}

Операційно-діяльнісний критерій сформованості готовності майбутніх фахівців служби циивільного захисту до самозбереження у професійній діяльності його показником $є$ сформованість проєктувально-конструктивних, виконавських та аналітико-рефлексивних умінь і навичок курсанта щодо здійснення самозбереження у професійній діяльності.

3 метою встановлення цього критерію була зроблена діагностична картка для оцінювання рівнів сформованості проєктувально-конструктивних, виконавських та аналітико-рефлексивних умінь і навичок курсанта щодо здійснення самозбереження у професійній діяльності. Курсанти здійснювали самооцінку запропонованих у діагностичній картці умінь і навичок за такою шкалою: високий рівень - 1 бал, середній рівень - 0,5 бала, низький рівень $-0,3$ бала.

Експертна оцінка проводилася двома експертами, якими були провідні фахівці служби цивільного захисту, викладачі навчальних дисциплін “Домедична допомога”, “Охорона праці”, “Психологічна підготовка”. Підсумкова оцінка виставлялася за результатами самооцінки курсанта та двох експертних оцінок.

Високий рівень оволодіння майбутніми фахівцями служби цивільного захисту проєктувально-конструктивними, виконавськими та аналітико-рефлексивними уміннями i навичками визначався наявністю 2,5-3 балів, середній рівень - 1,3-2,4 бала, низький рівень 0,9-1,2 бала.

Рефрлексивно-аналітичний критерій сформованості готовності майбутніх фахівців служби циивільного захисту до самозбереження у професійній діяльності показником якого $є$ повнота прояву соціальної креативності курсанта, його здатність до самоосвіти і саморозвитку для ефективного здійснення самозбереження у професійній діяльності [10].

Тест для визначення рівня соціальної креативності особистості. Соціальна креативність - це здатність нестандартно, творчо підходити до розв'язання соціальних проблем та складних професійних ситуацій. Для майбутнього фахівця служби цивільного захисту важливо вміти оперативно шукати і ефективно застосовувати нестандартні, оригінальні творчі вирішення професійних ситуацій у самозбереженні у професійній діяльності. Основою для цілеспрямованого розвитку цієї здібності виступає комплекс властивостей, що складають творчий i комунікативний потенціали особистості. Творчий потенціал - система властивостей особистості (мотиваційних, інтелектуальних, емоційних, вольових), що дає змогу творити, знаходити нове, приймати рішення та діяти нестандартно. Комунікативний потенціал $\epsilon$ системою властивостей і здібностей, що забезпечують участь особистості в комунікації і взаємодії з іншими людьми.

Працюючи 3 тестом для визначення соціальної креативності особистості, курсанти проводили самооцінку особистісних якостей або частоту їх прояву в певних життєвих ситуаціях за 9-бальною шкалою. Високий рівень соціальної креативності курсанта визначався наявністю 130-162 балів, середній рівень - 85-129 балів, низький рівень - 18-84 бали.

Тест для визначення здатності до самоосвіти та саморозвитку особистості.

В інструкції до тесту йдеться, що психолого-методичні можливості саморозвитку особистості, ефективність цього процесу багато в чому залежать від того, якими принципами та правилами керується людина у своїй життєдіяльності, адже кожен під час праці та безперервного самоудосконалення створює принципи і правила саморозвитку для себе сам. Спираючись на ці принципи і правила, можна наблизити рівень професійних якостей майбутніх фахівців до вимог, що потрібні для успішної професійної діяльності та зафіксовані у моделі їх професійної підготовки.

Працюючи 3 тестом для визначення здатності до самоосвіти та саморозвитку особистості, курсанти обирали один із запропонованих варіантів відповідей: “ні” - 1 бал, “частково, періодично” - 2 бали, “так” - 3 бали. Загальна кількість балів, набраних курсантом, співвідносилася зі шкалою визначення рівнів розвитку: високий рівень розвитку здатності курсанта до самоосвіти та саморозвитку визначався наявністю 50-63 балів, середній рівень -37-49 балів, низький рівень - 21-36 балів.

Висновки. Отже, визначено зміст основних етапів організації дослідження щодо підготовки майбутніх фахівців служби цивільного захисту до самозбереження у професійній діяльності: теоретико-пошукового, теоретико-методологічного, експериментально-аналітичного іузагальнювального. 3'ясовано завдання проведення констатувального та формувального етапів педагогічного експерименту. Описано етапи включення моделі підготовки майбутніх фахівців служби цивільного захисту до самозбереження у професійній діяльності. Охарактеризовано методики діагностики критеріїв сформованості структурних компонентів готовності майбутніх фахівців служби цивільного захисту до самозбереження у 


\section{МЕТОДИКИ ОЦІНКИ КРИТЕРЇВ СФОРМОВАНОСТІ СТРУКТУРНИХ КОМПОНЕНТІВ \\ ГОТОВНОСТІ МАЙБУТНІХ ФАХІВЦІВ СЛУЖБИ ЦИВІЛЬНОГО ЗАХИСТУ ДОСАМОЗБЕРЕЖЕННЯ У ПРОФЕСІЙНІЙ ДІЯЛЬНОСТІ}

професійній діяльності (мотиваційного, когнітивного, операційно-діяльнісного, рефлексивно-аналітичного). Розкрито методику роботи 3 комп'ютерною програмою для оцінки рівнів сформованості готовності майбутніх фахівців служби цивільного захисту до самозбереження у професійній діяльності.

\section{ЛІТЕРАТУРА}

1. Антонов А. Самосохранительное поведение. Народонаселение: энциклопедический словарь. Москва, 1994.

2. Березутский Ю. Самосохранительное поведение студентов: ценностный ресурс здоровья или декларация. Власть и управление на Востоке России. Хабаровск: ДВАГС, 2010. № 4. C. 152-159.

3. Брызгалова С. Формирование в вузе готовности учителя к педагогическому исследованию: теория и практика: научное издание. Калининград: Изд-во КГУ, 2004. 344 с.

4. Віговська О. Самореалізація як ознака конструктивного самозбереження особистості. Проблеми сучасної психології. Кам'янецьПодільський, 2014. Вип. 23. С. 90-99.

5. Горяна Л. Особливості духовно-ціннісного впливу підготовки молоді щодо навчання самозбереженню. Духовність особистості. Луганськ, 2012. Вип. 5. С. 63-71.

6. Кайдалова Л., Пляха Л. Психологія спілкування: навчальний посібник. Харків: НФаУ, 2011. 132 с.

7. Когут І. Формування професійно-педагогічної комунікативної компетентності майбутнього вчителя: дис. канд. пед. наук: 13.00.04. Полтава, 2015. $250 \mathrm{c}$.

8. Розин В. Здоровье как философская и социально-психологическая проблема. Мир психологии 2000. № 1 С. 12-31.

9. Таймасов Ю., Турчинов А., Пашинський П. Здоров'язбереження як об'єкт наукового пізнання. Загальна теорія здоров'я та здоров'язбереження: колективна монографія/ за заг. ред. проф. Ю.Д. Бойчука. Харків: Вид. Рожко С.Г., 2017. 488 с.

10. Таймасов Ю., Зуб О. Технології збереження психічного здоров'я студентів у роботі психологічної служби закладу вищої освіти. Сучасні здоров'язбережувальні технології : монографія/ за заг. ред. проф. Ю.Д. Бойчука. Харків: Оригінал, 2018. 724 с.

\section{REFERENCES}

1. Antonov, A. (1994). Samosokhranitelnoe povedenie. Narodonaselenie: entsiklopedicheskiy slovar [Self-preservation behavior. Population: Encyclopedic Dictionary]. Moscow. [in Russian].
2. Berezutskiy, Yu. (2010). Samosokhranitelnoe povedenie studentov: tsennostnyy resurs zdorovya ili deklaratsiya. Vlast i upravlenie na Vostoke Rossii [Self-preservation behavior of students: a value resource of health or a declaration. Power and control in the East of Russia]. Khabarovsk, vol. 4, pp. 152 159. [in Russian].

3. Bryzgalova, S. (2004). Formirovanie v vuze gotovnosti uchitelya $\mathrm{k}$ pedagogicheskomu issledovaniyu: teoriya i praktika: nauchnoe izdanie [Formation of the teacher's readiness for pedagogical research at the university: theory and practice: scientific publication]. Kaliningrad. 344 p. [in Russian].

4. Vighovsjka, O. (2014). Samorealizacija jak oznaka konstruktyvnogho samozberezhennja osobystosti [Self-realization as a sign of constructive self-preservation of the individual]. Problems of modern psychology, vol. 23, pp. 90-99. [in Ukrainian].

5. Ghorjana, L. (2012). Osoblyvosti dukhovnocinnisnogho vplyvu pidghotovky molodi shhodo navchannja samozberezhennju [Features of the spiritual and value impact of training young people to learn self-preservation]. Spirituality of personality, vol. 5, pp. 63-71.[in Ukrainian].

6. Kajdalova, L. \& Pljakha, L. (2011). Psykhologhija spilkuvannja: navchaljnyj posibnyk [Psychology of communication: a tutorial]. Kharkiv, 132 p. [in Ukrainian].

7. Koghut, I. (2015). Formuvannja profesijnopedaghoghichnoji komunikatyvnoji kompetentnosti majbutnjogho vchytelja [Formation of professional and pedagogical communicative competence of the future teacher]. Ccandidate's thesis. Poltava, 250 p. [in Ukrainian].

8. Rozin, V. (2000). Zdorove kak filosofskaya i sotsialno-psikhologicheskaya problema [Health as a philosophical and socio-psychological problem]. World of psychology, vol. 1, pp. 12-31.[in Russian].

9. Tajmasov, Ju., Turchynov, A. \& Pashynsjkyj, P. (2017). Zdorovjazberezhennja jak objekt naukovogho piznannja. Zaghaljna teorija zdorovja ta zdorovjazberezhennja [Healthcare as an object of scientific knowledge. The general theory of health and healthcare]. Kharkiv, 488 p. [in Ukrainian].

10. Tajmasov, Ju. \& Zub, O. (2018). Tekhnologhiji zberezhennja psykhichnogho zdorovja studentiv u roboti psykhologhichnoji sluzhby zakladu vyshhoji osvity. Suchasni zdorovjazberezhuvaljni tekhnologhiji [Technologies for maintaining the mental health of students in the work of the psychological service of higher education. Modern healthcare technologies]. Kharkiv, 724 p. [in Ukrainian].

Стаття надійшла до редакції 24.09.2020 